\title{
TOAST 1.0: Tropospheric Ozone Attribution of Sources with Tagging for CESM 1.2.2
}

\author{
Tim Butler ${ }^{1}$, Aurelia Lupascu ${ }^{1}$, Jane Coates $^{1}$, and Shuai Zhu ${ }^{1, a}$ \\ ${ }^{1}$ Institute for Advanced Sustainability Studies, Potsdam, Germany \\ a now at: China Unicom System Integration Limited Corporation, Beijing, China
}

Correspondence: Tim Butler (tim.butler@iass-potsdam.de)

Received: 26 February 2018 - Discussion started: 12 March 2018

Revised: 5 June 2018 - Accepted: 13 June 2018 - Published: 13 July 2018

\begin{abstract}
A system for source attribution of tropospheric ozone produced from both $\mathrm{NO}_{x}$ and volatile organic compound (VOC) precursors is described, along with its implementation in the Community Earth System Model (CESM) version 1.2.2 using CAM4. The user can specify an arbitrary number of tag identities for each $\mathrm{NO}_{x}$ or VOC species in the model, and the tagging system rewrites the model chemical mechanism and source code to incorporate tagged tracers and reactions representing these tagged species, as well as ozone produced in the stratosphere. If the user supplies emission files for the corresponding tagged tracers, the model will produce tagged ozone tracers which represent the contribution of each of the tag identities to the modelled total tropospheric ozone. Our tagged tracers preserve $\mathrm{O}_{x}$. The size of the tagged chemical mechanism scales linearly with the number of specified tag identities. Separate simulations are required for $\mathrm{NO}_{x}$ and VOC tagging, which avoids the sharing of tag identities between $\mathrm{NO}_{x}$ and VOC species. Results are presented and evaluated for both $\mathrm{NO}_{x}$ and VOC source attribution. We show that northern hemispheric surface ozone is dominated year-round by anthropogenic emissions of $\mathrm{NO}_{x}$, but that the mix of corresponding VOC precursors changes over the course of the year; anthropogenic VOC emissions contribute significantly to surface ozone in winter-spring, while biogenic VOCs are more important in summer. The system described here can provide important diagnostic information about modelled ozone production, and could be used to construct source-receptor relationships for tropospheric ozone.
\end{abstract}

\section{Introduction}

Tropospheric ozone is an important air pollutant, as well as a contributor to anthropogenic radiative forcing of the climate (Monks et al., 2015). Major sources of ozone in the troposphere are transport from the stratosphere, and photochemical production involving reactions of oxides of nitrogen (NO and $\mathrm{NO}_{2}$, collectively $\mathrm{NO}_{x}$ ) and volatile organic compounds (VOCs), including methane. Almost all of this photochemical production is related to the conversion of $\mathrm{NO}$ to $\mathrm{NO}_{2}$ by reaction with a peroxy radical produced during the oxidation of VOCs (Atkinson, 2000). Due to its long lifetime in the troposphere (several weeks), ozone can be transported over intercontinental distances. Concentrations of ozone observed at any given location can be due to both transported ozone from elsewhere and ozone produced from precursors emitted nearby.

Global chemistry-climate models are important tools for understanding the complex processes of chemistry and transport which affect tropospheric ozone, simulating its evolution and distribution under future climate change and projecting how this may change in response to precursor emission controls. Based on a suite of model simulations from ACCMIP (Atmospheric Chemistry and Climate Model Intercomparison Project) (Lamarque et al., 2013), Young et al. (2013) found that while the ensemble average of modelled ozone mixing ratios generally agreed with the present-day distribution of tropospheric ozone well, the individual models showed large differences from each other. Furthermore, the models generally agreed on the sign of the difference among present-day and both pre-industrial and future (late 2100s) conditions, but they tended to disagree strongly on the magnitude of these changes. The current state-of-the-art 
models show differing sensitivities in tropospheric ozone to changes in both climate and precursor emissions. In a more detailed comparison of the ACCMIP models with observed datasets, Parrish et al. (2014) showed that the models are not able to simulate the observed long-term changes in tropospheric ozone, and concluded that more work is needed to improve the representation of chemistry and transport processes in models, as well as our understanding of historical emission changes, before the models could be reliably used to simulate future changes in tropospheric ozone. Young et al. (2013) identified the need for improved diagnostic information about modelled ozone budgets in order to understand the differences among models.

Intercontinental source-receptor relationships for tropospheric ozone have been modelled in the HTAP (Hemispheric Transport of Air Pollution) project using a perturbation methodology in which emissions of ozone precursors in source regions are reduced by some fraction (e.g. 20\%), and the resulting modelled ozone concentrations in receptor regions are compared with a base simulation in which the emissions were not perturbed (Fiore et al., 2009). An alternative approach for determining source-receptor relationships in model runs is a technique known as "tagging", in which ozone molecules are labelled with the identity of their source, allowing direct attribution of ozone concentrations to these sources in receptor regions (e.g. Wang et al., 1998; Dunker et al., 2002; Sudo and Akimoto, 2007; Grewe et al., 2010, 2017; Emmons et al., 2012; Derwent et al., 2015; Kwok et al., 2015; Guo et al., 2017). Tagging (source apportionment) methodologies are complementary to perturbation (sensitivity) methodologies (Emmons et al., 2012; Grewe et al., 2017; Clappier et al., 2017). While tagging approaches produce information about the contribution of different precursors to the total amount of ozone in a simulation, perturbation approaches produce information about the response of ozone in a simulation to changes in emissions. Grewe et al. (2017) showed that when individual emission sources are perturbed, the contribution of other sources to the total amount of modelled ozone can also change. A combination of the perturbation and tagging methodologies can provide information about these changes in source contributions under perturbed emission scenarios. Since tagging methods can deliver detailed information about the provenance of modelled ozone concentrations, they could potentially also be a useful tool for understanding the differences among models.

In this paper we describe and characterize a novel method for tagged source attribution of tropospheric ozone and contrast our approach with previous work. We present a review of prior tagging approaches in Sect. 2, then describe the implementation of our method in CESM 1.2.2 with CAM4 (Tilmes et al., 2015; Lamarque et al., 2012) in Sect. 3. The design of our model evaluation experiments is described in Sect. 4, and we evaluate and compare the results for both $\mathrm{NO}_{x}$ and VOC tagging in Sect. 5. Conclusions and outlook are presented in Sect. 6.

\section{Review of tagging methods}

There are many different examples of several different approaches to ozone tagging in both regional and global models. In this study, we focus on the attribution of ozone production to emitted precursors. Studies such as Wang et al. (1998), Sudo and Akimoto (2007), and Derwent et al. (2015) each tag ozone molecules based on the geographical model domains in which the ozone molecules are formed; thus they do not directly attribute chemical ozone production to emissions of particular precursors, and will not be discussed further here.

Attribution of ozone production to emissions in models of atmospheric chemistry involves several design decisions and associated trade-offs:

- Is ozone production attributed to emissions of $\mathrm{NO}_{x}$, VOC, or both? And if both, how is the chemical regime $\left(\mathrm{NO}_{x}\right.$ or VOC limited) accounted for?

- Is ozone production attributed explicitly for each chemical reaction producing ozone, or is the total instantaneous ozone production in each grid cell attributed according to the proportion of each precursor present?

- Are tagged precursor species simulated explicitly, or are they grouped into chemical "families"?

- How does the tagging system treat the $\mathrm{O}_{3}-\mathrm{NO}_{x}$ null chemical cycle?

Since both $\mathrm{NO}_{x}$ and VOC are involved in the chemical production of ozone, most tagging schemes attempt to attribute ozone production to both of these types of precursors. Two approaches for simultaneous attribution of ozone to both $\mathrm{NO}_{x}$ and VOC have been used: determination of the chemical regime with attribution to the limiting precursor (either $\mathrm{NO}_{x}$ or VOC) and equal attribution to both $\mathrm{NO}_{x}$ and VOC precursors. In each case, additional tracers are added to the model, and track the emissions of $\mathrm{NO}_{x}$ and VOC species, which are typically labelled with the identities of their source sectors (e.g. transport, industry) or source regions (e.g. East Asia, North America).

Determination of the chemical regime is typically made according to the indicator ratio $\mathrm{PH}_{2} \mathrm{O}_{2} / \mathrm{PHNO}_{3}$ (the ratio between the production rates of hydrogen peroxide and nitric acid). According to Sillman (1995) the chemical regime is $\mathrm{NO}_{x}$ or VOC limited if the ratio of total peroxide (hydrogen peroxide plus organic peroxides) production to nitric acid production is above or below 0.5 , respectively, but that the $\mathrm{PH}_{2} \mathrm{O}_{2} / \mathrm{PHNO}_{3}$ ratio can be used with a threshold value of 0.35 as an approximation for the chemical regime transition. This approach somewhat simplifies the highly complex chemistry of ozone production, in which there is a transition regime of sensitivity to both $\mathrm{NO}_{x}$ and VOC emissions. This approach is also typically used in regional modelling studies, in which model grid cells are relatively small (compared with 
global models). VOC-limited chemical regimes are typically found in regions of very high $\mathrm{NO}_{x}$ emissions, such as urban areas, which are not well resolved by global models. Dunker et al. (2002) and Kwok et al. (2015) describe the use of this technique in the regional models CAMx and CMAQ, respectively. In both cases, the tagging scheme determines whether ozone production in each model grid cell is in a $\mathrm{NO}_{x}$-limited or a VOC-limited chemical regime, and attributes all instantaneous ozone production to the limiting precursor, with tagged ozone tracers added in proportion to the relative concentrations of the tagged precursor tracers present in that grid cell. Tagged ozone tracers are chemically destroyed according to the modelled instantaneous ozone chemical loss rate. Such tagging schemes account for the rapid null cycles involving $\mathrm{O}_{x}$ species by not considering their cycling reactions as part of the instantaneous ozone production or loss rates.

We are not aware of any global modelling study which has attempted to attribute ozone production to $\mathrm{NO}_{x}$ or VOC precursors based on the chemical regime in each grid cell. Instead, ozone tagging at the global scale has been performed either by focusing on only $\mathrm{NO}_{x}$ precursors (e.g. Emmons et al., 2012) or by giving equal weight to both $\mathrm{NO}_{x}$ and VOC precursors (e.g. Grewe et al., 2010, 2017; Guo et al., 2017). Grewe et al. $(2010,2017)$ use a similar approach to Dunker et al. (2002) and Kwok et al. (2015) in that they make use of the instantaneous ozone production rate modelled at each time step to determine the production rate of tagged ozone, but instead of allocating this ozone production to either $\mathrm{NO}_{x}$ or VOC based on the determination of a chemical regime, the tagged ozone molecules inherit their tag identities from a combination of both tagged $\mathrm{NO}_{x}$ and VOC depending on their abundances relative to the total amount of $\mathrm{NO}_{x}$ and VOC present in each grid cell at each time step. Emmons et al. (2012) and Guo et al. (2017) take a different approach, and add extra reactions to the base chemical mechanism representing the transformations of the tagged precursors and the production of tagged ozone, relying instead on the chemical solver of their model to calculate the production and loss rates of tagged species.

Similar to Grewe et al. (2010, 2017), Guo et al. (2017) also take a combinatorial approach to the simultaneous attribution of tagged ozone to both $\mathrm{NO}_{x}$ - and VOC-tagged precursors. They avoid the chemical mechanism becoming too large by only considering two tag identities ("East Asia" (EA) and "everywhere else" (EE)). Each reaction between a peroxy radical and NO then requires four corresponding tagged reactions: EA + EA, EA + EE, EE + EA, and EE + EE. The size of their tagged mechanism thus increases quadratically with the number of tag identities. In the case of the cross reactions (EA + EE and $\mathrm{EE}+\mathrm{EA})$, the $\mathrm{NO}_{2}$ produced from the reaction between $\mathrm{NO}$ and a peroxy radical is split into equal parts $\mathrm{NO}_{2}$ from $\mathrm{EA}$ and $\mathrm{NO}_{2}$ from $\mathrm{EE}$, despite the fact that the NO reactant in any given reaction can only have come from one of these regions. By using such a combinatorial approach, Grewe et al. $(2010,2017)$ and Guo et al. (2017) allow the transfer of tag identities between $\mathrm{NO}_{x}$ and VOC species, which can produce tagged tracer concentrations which have no physical meaning. For example, Fig. 5b of Grewe et al. (2017) attributes approximately $10 \mathrm{Tg}$ of $\mathrm{CO}$ production per year to lightning, despite the fact that lightning is only a source of $\mathrm{NO}_{x}$ in their model. Such an unphysical result could be obtained in their tagging scheme after decomposition of a molecule of PAN (peroxy acetyl nitrate, an organic nitrate), which had been tagged as coming from $\mathrm{NO}_{x}$ due to lightning. A similarly unphysical transfer of tag identity would be obtained in the approach used by Guo et al. (2017) if lightning were chosen as one of their tag identities.

The treatment of the $\mathrm{NO}_{x}-\mathrm{O}_{3}$ chemical cycle is another area in which ozone-tagging schemes can produce unphysical results. As pointed out by Kwok et al. (2015), the approach of Emmons et al. (2012) treats the reaction between $\mathrm{NO}$ and $\mathrm{O}_{3}$ (forming $\mathrm{NO}_{2}$ ) as chemical destruction of $\mathrm{O}_{3}$. The subsequent rapid reformation of $\mathrm{O}_{3}$ from $\mathrm{NO}_{2}$ photolysis is treated as new ozone production due to an emitted $\mathrm{NO}_{x}$ precursor, effectively "overwriting" the identity of tagged ozone from remote sources with the identity of tagged $\mathrm{NO}_{x}$ emissions from more nearby sources. The work of Grewe et al. (2017) does not suffer from this problem because ozone is included in a chemical family $\left(\mathrm{O}_{x}=\right.$ odd oxygen $=\mathrm{O}_{3}+\mathrm{O}+\mathrm{NO}_{2}+$ others), which is preserved during fast chemical exchanges. Guo et al. (2017) do not give enough information to determine whether their approach also suffers from this tag overwriting problem.

While the use of the $\mathrm{O}_{x}$ chemical family is essential to preserve the correct identity of tagged ozone species, the use of other chemical families for ozone precursors can introduce additional problems with tagging schemes. For example, Grewe et al. (2017) do not explicitly follow the propagation of tags through the full set of VOC oxidation intermediates, but instead only tag a single "NMHC" (non-methane hydrocarbon) chemical family, which includes all VOC oxidation intermediate species, including the oxidation products of methane, but excludes PAN. Their use of this NMHC family leads to the unphysical result from their Fig. 5d, in which formation of PAN has been partially attributed to methane. There is no known chemical pathway in the atmosphere capable of transforming methane into PAN. This is not an inherent weakness of their tagging approach, but rather results from their choice of one chemical family to represent all VOC ozone precursors. In order to avoid such unphysical results, the choice of chemical families must be made carefully. Ideally, each individual VOC oxidation intermediate should be explicitly tagged.

Butler et al. (2011) introduced a method for recursively tagging all reactions involving VOC species in a chemical box model. They followed and tagged the oxidation pathways of all VOC intermediate products until they were fully oxidized, and thus no longer included in the chemical mechanism. Butler et al. (2011) used this method to determine the time-dependent ozone production potential of all VOC 
species in the MCM (Master Chemical Mechanism; Saunders et al. (2003)) by tagging each of the "primary" (emitted) VOCs with its own identity, and were thus able to attribute ozone production from intermediate VOC species back to the emissions of each primary VOC species, thus avoiding the use of a generic VOC chemical family. Butler et al. (2011) showed that the chemistry of VOC intermediate products can contribute significantly to the total ozone production from VOC over the timescales of several days after emission. Using this approach, it was feasible to tag each primary VOC and all of its intermediate oxidation products in the MCM with a unique tag, due to the way in which the interactions among different organic peroxy radicals are treated in the MCM. The peroxy-peroxy chemistry of each individual peroxy radical in the MCM is represented as a unimolecular decay reaction with a rate constant proportional to the total concentration of all other peroxy radicals. As also noted by Ying and Krishnan (2010), if these peroxy-peroxy reactions are treated explicitly in a tagged chemical mechanism, the size of the tagged mechanism would scale quadratically with the number of tags, which would rapidly become too large for practical use. The technique of Butler et al. (2011) was subsequently applied for comparison of several VOC oxidation mechanisms by Coates and Butler (2015). In order to avoid the quadratic scaling problem, the chemistry of the organic peroxy radicals in each chemical mechanism was rewritten in the MCM style, allowing the size of the tagged chemical mechanism to scale linearly with the number of tag identities.

\section{Implementation of $\mathrm{NO}_{x}$ and VOC tagging}

In this paper we describe an extension to the ozone-tagging system first described fully by Emmons et al. (2012). This extended tagging system improves upon the earlier work of Emmons et al. (2012), avoiding the various problems with previous tagging schemes described above.

- Our tagging scheme allows an arbitrary number of userdefined tag names in a single model run, with the size of the chemical mechanism increasing linearly with the number of tag identities.

- Our tagging scheme introduces new tagged tracers for members of the $\mathrm{O}_{x}$ chemical family (which avoids the problem that ozone tags are destroyed by the null cycle involving $\mathrm{NO}_{x}$ ).

- Our tagging scheme incorporates the recursive VOCtagging system of Butler et al. (2011), explicitly tagging each intermediate VOC and avoiding the use of precursor families.

- Our tagging scheme avoids the possibility of VOC species being tagged with identities of $\mathrm{NO}_{x}$ species (and vice versa) by requiring that two separate model runs be performed, one with $\mathrm{NO}_{x}$ tagging, and another with
VOC tagging. The tagged $\mathrm{O}_{x}$ produced during the conversion of $\mathrm{NO}$ to $\mathrm{NO}_{2}$ can only be assigned to the tagged identity of the NO precursor, or the tagged identity of the peroxy radical involved in each such transformation, depending on whether $\mathrm{NO}_{x}$ or VOC tagging is being used.

The extended tagging system allows a completely closed source attribution of tropospheric ozone to all precursors to be performed in two model runs, one with $\mathrm{NO}_{x}$ tagging, and another with VOC tagging.

The tagging system is implemented as software, which takes as input an arbitrary list of chemical species to be tagged (typically precursor emissions), and for each of these species, an arbitrary list of tags to be applied. The tagging system rewrites the model chemical mechanism and CAM4 source files to include a new set of tracers and reactions corresponding to these user-specified tagged species and their associated chemical reactions. As one possible example, if the user specifies that the tags "anthropogenic" and "biogenic" are to be applied to the species $\mathrm{NO}$ and $\mathrm{NO}_{2}$, the chemical mechanism file will be modified to include all necessary species and reactions such that the model will be able to simulate ozone due to $\mathrm{NO}_{x}$ emitted by anthropogenic and biogenic sources. Other possibilities are tagging emissions based on geographical source regions, the time at which they were emitted, et cetera. In each case, the user must supply appropriate input files containing the emissions of each of the tagged species in order for the additional tagged reactions and tracers to have any effect. After some initial manual modifications are made to the chemical mechanism and model source files (described below), the specification of a new set of tags representing emitted precursors is a completely automated process. The full suite of tagging tools, input files, and machine-readable tagged mechanism files are included in the Supplement.

Due to the different requirements of $\mathrm{NO}_{x}$ and VOC tagging, the user must explicitly choose whether $\mathrm{NO}_{x}$ or VOC tagging is to be performed. The $\mathrm{NO}_{x}$-tagging approach is described in Sect. 3.1, and the VOC-tagging approach is described in Sect. 3.2. The resulting complete lists of both $\mathrm{NO}_{x}$-tagged reactions and VOC-tagged reactions are included in both machine- and human-readable forms in the Supplement. The size of the modified chemical mechanism scales linearly with the number of tag identities requested by the user. The tagging system also modifies all model source files which contain code in which the tagged species are modified by other modelled processes such as deposition (dry and wet) and input or removal due to boundary conditions. The source code modification, including a full list of the source files which are modified, is described in more detail in Sect. 3.3.

Due to the potentially large number of additional reactions and species introduced into the chemical mechanism, it was necessary to modify the chemical mechanism preprocessor 
shipped with CESM1.2.2 to raise some hard-coded limits and ensure that the addition of the tagged reactions containing untagged species from the base mechanism does not alter the treatment of the untagged species in the chemical solver. The modified source code of the chemical preprocessor is included in the Supplement.

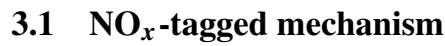

The base chemical mechanism used here is taken from Emmons et al. (2012). The same base mechanism is used for both $\mathrm{NO}_{x}$ and VOC tagging. Following Emmons et al. (2012), the reactions of tagged species are implemented as additional reactions in the model chemical mechanism file involving both tagged and untagged reactants. Untagged reactants appear in stoichiometrically identical amounts in the reactants and products of each tagged reaction, so that tagged reactions do not alter the concentrations of untagged species.

\subsubsection{Separation of $\mathrm{NO}_{y}$ and $\mathrm{O}_{x}$ tagged species}

In order to allow an arbitrary number of tags in a single model run, and to avoid the tag overwriting problem described in Sect. 2, the chemical families $\mathrm{NO}_{y}$ (which includes $\mathrm{NO}_{x}$ and all $\mathrm{NO}_{x}$ reservoir species) and $\mathrm{O}_{x}$ are tagged separately. The following species from the base chemical mechanism belong to the $\mathrm{NO}_{y}$ family: $\mathrm{NO}, \mathrm{NO}_{2}, \mathrm{NO}_{3}$, $\mathrm{N}_{2} \mathrm{O}_{5}, \mathrm{HNO}_{3}, \mathrm{HO}_{2} \mathrm{NO}_{2}, \mathrm{ISOPNO}_{3}$, ONIT, ONITR, PAN, and MPAN. The following species from the base chemical mechanism belong to the $\mathrm{O}_{x}$ family: $\mathrm{O}_{3}, \mathrm{O}\left({ }^{1} \mathrm{D}\right), \mathrm{O}, \mathrm{NO}_{2}$, $\mathrm{NO}_{3}, \mathrm{~N}_{2} \mathrm{O}_{5}, \mathrm{HNO}_{3}, \mathrm{HO}_{2} \mathrm{NO}_{2}, \mathrm{ISOPNO}_{3}$, ONIT, ONITR, PAN, and MPAN. When performing VOC tagging, $\mathrm{HO}_{2}$ is added to the $\mathrm{O}_{x}$ family (see Sect. 3.2.1 for more details).

Following Butler et al. (2011) we regard the reaction of $\mathrm{NO}$ with any peroxy radical $\left(\mathrm{HO}_{2}\right.$ and all organic peroxy radicals) and subsequent production of $\mathrm{NO}_{2}$ as the process which effectively generates tropospheric ozone.

$\mathrm{NO}+\mathrm{HO}_{2} \rightarrow \mathrm{NO}_{2}+\mathrm{OH}$

Reaction (R1) from the base chemical mechanism is represented in our tagging system as follows:

$\mathrm{NO} \_\mathrm{TAG}+\mathrm{HO}_{2} \rightarrow \mathrm{NO}_{2}$ TAG $+\mathrm{NO}_{2} \_$X_TAG $+\mathrm{HO}_{2}$.

Since $\mathrm{NO}_{2}$ is in both the $\mathrm{NO}_{y}$ and $\mathrm{O}_{x}$ chemical families, two different tagged versions of $\mathrm{NO}_{2}$ are produced in Reaction (R2) and they represent the distinct roles of $\mathrm{NO}_{2}$ in each of these chemical families: $\mathrm{NO}_{2}$ TAG is $\mathrm{NO}_{y}$-tagged $\mathrm{NO}_{2}$ while $\mathrm{NO}_{2} \_\mathrm{X} \_\mathrm{TAG}$ is $\mathrm{O}_{x}$-tagged $\mathrm{NO}_{2}$. The suffix "_TAG" is a placeholder which can be replaced by the tagging system with an arbitrary number of user-chosen tag identities, each of which is represented by a unique reaction added to the tagged chemical mechanism. The suffix “_X_TAG” represents members of the $\mathrm{O}_{x}$ chemical family produced from emitted $\mathrm{NO}_{x}$ species tagged with the identity "TAG". Additional reactions of $\mathrm{O}_{x}$ species are discussed below.
In the base chemical mechanism, ozone is produced from $\mathrm{NO}_{2}$ via photolysis.

$\mathrm{NO}_{2}+\stackrel{h v}{\longrightarrow} \mathrm{NO}+\mathrm{O}$

$\mathrm{O}+\mathrm{O}_{2} \rightarrow \mathrm{O}_{3}$

The NO produced from Reaction (R3) is then available for additional reaction with a peroxy radical, while the atomic $\mathrm{O}$ goes on to produce $\mathrm{O}_{3}$. In the tagged chemical mechanism, the fate of $\mathrm{O}_{x}$-tagged $\mathrm{NO}_{2}$ is different from that of $\mathrm{NO}_{y}$ tagged $\mathrm{NO}_{2}$.

$\mathrm{NO}_{2}$ TAG $+\stackrel{h v}{\longrightarrow}$ NO_TAG

$\mathrm{NO}_{2} \_\mathrm{X} \_\mathrm{TAG}+\stackrel{h v}{\longrightarrow}$ O_X_TAG

$\mathrm{O} \_\mathrm{X} \_\mathrm{TAG}+\mathrm{O}_{2} \rightarrow \mathrm{O}_{3} \_\mathrm{X} \_\mathrm{TAG}+\mathrm{O}_{2}$

In the tagged versions of Reactions (R3)-(R4), tagged ozone is produced from tagged $\mathrm{O}_{x}$ in Reaction (R6), while the tagged $\mathrm{O}_{x}$ precursor NO remains available for further subsequent conversion of $\mathrm{NO}$ to $\mathrm{NO}_{2}$ after its regeneration in Reaction (R5).

The tag overwriting problem (Sect. 2) emerges from the reaction between ozone and NO.

$\mathrm{NO}+\mathrm{O}_{3} \rightarrow \mathrm{NO}_{2}+\mathrm{O}_{2}$

Because Emmons et al. (2012) did not clearly distinguish the $\mathrm{NO}_{y}$ and $\mathrm{O}_{x}$ chemical families in their tagging system, their tagged $\mathrm{NO}_{2}$ effectively inherited its tag from $\mathrm{NO}$, leading to the replacement of tagged ozone identities by the $\mathrm{O}_{3}-$ $\mathrm{NO}_{x}$ null chemical cycle. This has the effect that tag identities from nearby sources of $\mathrm{NO}_{x}$ are over-represented in the tagged $\mathrm{O}_{3}$ in the study of Emmons et al. (2012).

In our tagging system, we avoid this problem by handling Reaction (R8) as follows.

$\mathrm{NO} \_\mathrm{TAG}+\mathrm{O}_{3} \rightarrow \mathrm{NO}_{2} \_\mathrm{TAG}+\mathrm{O}_{3}$

$\mathrm{NO}+\mathrm{O}_{3} \_\mathrm{X} \_\mathrm{TAG} \rightarrow \mathrm{NO}_{2} \_\mathrm{X} \_\mathrm{TAG}+\mathrm{NO}$

The tagged identity of the emitted $\mathrm{NO}_{x}$ precursor is preserved in Reaction (R9), while the tagged identity of $\mathrm{O}_{x}$ is preserved in Reaction (R10).

A major sink pathway for tropospheric ozone is photolysis followed by reaction of excited oxygen atoms with water vapour, producing hydroxyl radicals.

$\mathrm{O}_{3}+\stackrel{h v}{\longrightarrow} \mathrm{O}\left({ }^{1} \mathrm{D}\right)+\mathrm{O}_{2}$

$\mathrm{O}\left({ }^{1} \mathrm{D}\right)+\mathrm{H}_{2} \mathrm{O} \rightarrow 2 \mathrm{OH}$

This loss process is represented in our tagging system as follows.

$\mathrm{O}_{3} \_\mathrm{X} \_\mathrm{TAG}+\stackrel{h v}{\longrightarrow} \mathrm{O}\left({ }^{1} \mathrm{D}\right) \_\mathrm{X} \_\mathrm{TAG}$

$\mathrm{O}\left({ }^{1} \mathrm{D}\right) \_\mathrm{X} \_\mathrm{TAG}+\mathrm{H}_{2} \mathrm{O} \rightarrow \mathrm{H}_{2} \mathrm{O}$

All of the tagged species also undergo further chemical transformations analogous to the reactions in the base chemical mechanism. Further details are given in the Supplement. 


\subsubsection{Preparation of the chemical mechanism for $\mathrm{NO}_{x}$ tagging}

Before the tagging system can automatically generate a tagged chemical mechanism file including the user-specified tag identities, a set of placeholder reactions must be added by hand to the base chemical mechanism. Machine-readable files containing these placeholder reactions can be found in the Supplement. In future versions of our tagging system, it may be possible to identify these reactions automatically. These reactions can be classified into a number of different categories based on their chemical characteristics.

1. Reactions of emitted $\mathrm{NO}_{x}$ and corresponding $\mathrm{NO}_{y}$ reservoir species. This category includes all reactions between NO and peroxy radicals which generate $\mathrm{O}_{x}$ tagged $\mathrm{NO}_{2}\left(\mathrm{NO}_{2} \mathrm{X}_{-} \mathrm{TAG}\right)$.

2. Reactions of $\mathrm{O}_{x}$ species, including transformations between $\mathrm{O}_{x}$ family members, and sinks of $\mathrm{O}_{x}$. This category changes slightly depending on whether $\mathrm{NO}_{x}$ or VOCs are being tagged; for $\mathrm{NO}_{x}$ tagging, reactions of $\mathrm{OH}$ radicals with atomic $\mathrm{O}$ and molecular $\mathrm{O}_{3}$ are sinks of $\mathrm{O}_{x}$, while for VOC tagging these reactions preserve $\mathrm{O}_{x}$ (see Sect. 3.2.1 for more details).

3. Reactions which endogenously generate $\mathrm{NO}_{y}$ or $\mathrm{O}_{x}$ species. Stratospheric $\mathrm{O}_{3}$ is produced in this category of reactions, through the photolysis of $\mathrm{O}_{2}$ and $\mathrm{N}_{2} \mathrm{O}$, which ultimately produce the specially tagged species $\mathrm{O}_{3} \_\mathrm{X} \_\mathrm{STR}$. A small amount of atomic $\mathrm{O}$ is produced from the self-reaction of $\mathrm{OH}$ radicals, producing the specially tagged species "O_X_XTR" ("extra" sources). This category also changes slightly depending on whether $\mathrm{NO}_{x}$ or VOCs is being tagged. When $\mathrm{NO}_{x}$ are being tagged, reaction of $\mathrm{N}_{2} \mathrm{O}$ with excited oxygen in the stratosphere produces NO_STR, and the reactions of $\mathrm{HO}_{2}$ with certain organic peroxy radicals produce $\mathrm{O}_{3} \_\mathrm{X} \_\mathrm{XTR}$.

Similar to Emmons et al. (2012), the species $\mathrm{N}_{2} \mathrm{O}_{5}$, which is formed by reaction between $\mathrm{NO}_{2}$ and $\mathrm{NO}_{3}$, is duplicated to account for the possibility that its tag is inherited from either $\mathrm{NO}_{2}$ or $\mathrm{NO}_{3}$. The species $\mathrm{NO}_{3}$ is also subject to a tag inheritance problem when being tagged as a member of the $\mathrm{O}_{x}$ chemical family in the following reaction:

$\mathrm{NO}_{2}+\mathrm{O}_{3} \rightarrow \mathrm{NO}_{3}+\mathrm{O}_{2}$.

In this case, the $\mathrm{O}_{x}$ tag identity could be inherited from either $\mathrm{NO}_{2}$ or $\mathrm{O}_{3}$. Following Emmons et al. (2012) we simply let the $\mathrm{O}_{x}$ tag be inherited from $\mathrm{NO}_{2}$ in this case.

A full list of $\mathrm{NO}_{x}$-tagged reactions is given in the Supplement, including reactions producing species specially tagged as "STR" and "XTR".

\subsection{VOC-tagged mechanism}

Butler et al. (2011) introduced a methodology to recursively follow the chemistry of VOC species, starting from the emitted VOC, following all intermediate species, and ending when only unreactive products remain. For each intermediate species, additional reactions and tracers are added to the chemical mechanism and are tagged with the same identity as the originally emitted species. The added species include tagged organic peroxy radicals (generically represented here as $\mathrm{RO}_{2}$, but which are explicitly tagged by our tagging system). These $\mathrm{RO}_{2}$ produce $\mathrm{O}_{x}$ by converting $\mathrm{NO}$ to $\mathrm{NO}_{2}$ :

$$
\begin{aligned}
\mathrm{RO}_{2} \_\mathrm{TAG} & +\mathrm{NO} \rightarrow \mathrm{NO}+\mathrm{NO}_{2} \_\mathrm{X} \_\mathrm{TAG} \\
& + \text { tagged products. }
\end{aligned}
$$

The "tagged products" of Reaction (R16) include tagged versions of all of the intermediate VOCs associated with the corresponding reaction from the base chemical mechanism. Many such reactions also include $\mathrm{HO}_{2}$ as a product, which may go on to produce $\mathrm{O}_{x}$ by converting $\mathrm{NO}$ to $\mathrm{NO}_{2}$ (Reaction $\mathrm{R} 1$ ). In order to attribute this $\mathrm{O}_{x}$ production to the appropriate tag identity, $\mathrm{HO}_{2}$ is included in the $\mathrm{O}_{x}$ family when performing VOC tagging, and the $\mathrm{HO}_{2}$ produced in tagged organic reactions is given the identity of the organic reactant responsible for its production. The $\mathrm{HO}_{2} \_\mathrm{X}$ TAG thus produced gives its $\mathrm{O}_{x}$ tag to $\mathrm{NO}_{2}$ when reacting with $\mathrm{NO}$ :

$\mathrm{HO}_{2} \_\mathrm{X} \_\mathrm{TAG}+\mathrm{NO} \rightarrow \mathrm{NO}_{2} \_\mathrm{X} \_\mathrm{TAG}+\mathrm{NO}$.

(R17)

The tagging software automatically identifies reactions involving the user-specified primary (or emitted) VOC species in the base chemical mechanism and automatically generates tagged reactions of these species and their intermediates, including $\mathrm{NO}_{2}$ X_TAG and $\mathrm{HO}_{2} \mathrm{X}_{-} \mathrm{TAG}$, in the products where appropriate in order to attribute production of $\mathrm{O}_{x}$ to these emitted VOC species.

\subsubsection{Preparation of the chemical mechanism for VOC tagging}

In the case of VOC tagging, a number of reactions must be identified and categorized by hand, similar to the case of $\mathrm{NO}_{x}$ tagging described in Sect. 3.1.2.

1. Reactions involving $\mathrm{HO}_{2}$. These include Reaction (R17), reactions of the $\mathrm{HO}_{2}$ reservoir species $\mathrm{HO}_{2} \mathrm{NO}_{2}$, and sinks of $\mathrm{HO}_{2}$ which do not pass the tag identity onto their products (typically reactions of $\mathrm{HO}_{2}$ with $\mathrm{RO}_{2}$ species).

2. Reactions of $\mathrm{O}_{x}$ species, including transformations between $\mathrm{O}_{x}$ family members and sinks of $\mathrm{O}_{x}$. This category has substantial overlap with reactions involved in $\mathrm{NO}_{x}$ tagging, but with one small difference: since $\mathrm{HO}_{2}$ is considered a member of the $\mathrm{O}_{x}$ chemical family 
when tagging $\mathrm{VOC}$, the production of $\mathrm{HO}_{2}$ from reactions of $\mathrm{OH}$ radicals with atomic $\mathrm{O}$ and molecular $\mathrm{O}_{3}$ is not treated as a sink for $\mathrm{O}_{x}$ as it is for $\mathrm{NO}_{x}$ tagging (Sect. 3.1.2). Instead, the tagged identity is preserved as $\mathrm{HO}_{2} \_$X_TAG.

3. Reactions which endogenously generate $\mathrm{NO}_{y}$ or $\mathrm{O}_{x}$ species. This category also has substantial overlap with $\mathrm{NO}_{x}$ tagging, including the production of stratospheric $\mathrm{O}_{3}$ from photolysis $\mathrm{O}_{2}$. An additional reaction which is considered during VOC tagging is the production of the specially tagged species $\mathrm{HO}_{2} \_\mathrm{X} \_\mathrm{XTR}$ from the reaction between $\mathrm{OH}$ and $\mathrm{H}_{2} \mathrm{O}_{2}$.

Following Coates and Butler (2015), the chemistry of the organic peroxy radicals in the base chemical mechanism is modified here to use the permutation approach employed by the MCM, in which the cross reactions of individual $\mathrm{RO}_{2}$ species are represented as unimolecular decay reactions with rates proportional to the total concentration of all $\mathrm{RO}_{2}$ species. Further details are given in Coates and Butler (2015).

A full list of VOC-tagged reactions is given in the Supplement, including reactions producing species specially tagged as STR and XTR.

\subsection{Automatic source code rewriting}

Several of the CAM source code files must be modified in order to correctly handle the processes involving the tagged tracers. Source files are first modified by hand in such a way that they can be automatically rewritten by the tagging software to accommodate the tagged tracers, and will also compile and run correctly when the CAM is run without tagging enabled. This is accomplished by enclosing sections of relevant code between FORTRAN comments. For example, model variables which index the concentration array for tagged species are declared as follows.

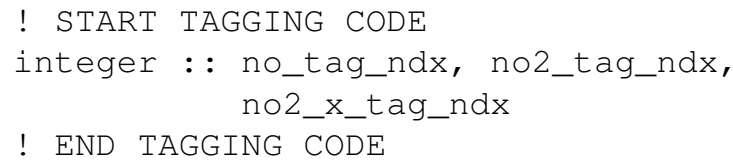

The tagging logic itself is similarly enclosed between comments. The tagging software scans each source file for these comment lines, and expands the code where appropriate, adding code for each tagged tracer which has been added to the chemical mechanism.

The modified files are listed here, along with short summaries of the changes made in each case. The hand-modified source files themselves, along with the tagging software and all other necessary input files, are available in the Supplement.

- cam_history.F90 Code is modified to account for the larger number of tracers which could potentially be written to history files.
- mo_aerosols.F90 Code for gas-aerosol partitioning of tag identities between ammonium nitrate and nitric acid is added.

- mo_airplane.F90 Code is added to tag emissions from aircraft with the hard-coded identity "AIR".

- mo_drydep.F90 Dry deposition fluxes are calculated for tagged species using deposition velocities of the corresponding untagged species.

- mo_flbc.F90 Species added at the lower model boundary are appropriately tagged if tags are defined for these species.

- mo_fstrat.F90 Tagged tracers are adjusted at the upper model boundary based on the adjustments made to the corresponding non-tagged species. Any $\mathrm{O}_{x}$ or $\mathrm{NO}_{y}$ added to the model is tagged as being of stratospheric origin. Other species are added or removed in proportion to their share of the corresponding untagged species.

- mo_gas_phase_chemdr.F90 Indices into the model concentration array for tagged species are determined during initialization.

- mo_imp_sol.F90 Relative error parameters for tagged species in the implicit solver are set to the same values as for the corresponding untagged species.

- mo_lightning.F90 Code is added to tag NO production from lightning with the hard-coded identity "LGT".

- mo_neu_wetdep.F90 Wet deposition fluxes are calculated for tagged species using removal rates of the corresponding untagged species.

- mo_photo.F90 Photolysis rates for the tagged reactions are set equal to the corresponding untagged reactions.

- mo_setext.F90 Code is added to facilitate the tagging of lightning NO and aircraft emissions.

- mo_sethet.F90 Loss rates due to heterogeneous chemistry are calculated for tagged species using removal rates of the corresponding untagged species.

- mo_srf_emissions.F90 Emissions of isoprene and monoterpenes are tagged appropriately if tags have been specified for these species.

- mo_usrrxt.F90 Rate constants of several of the tagged reactions are set equal to the rate constants of the corresponding untagged reactions. 


\section{Experiment design}

We use CESM version 1.2.2 (Tilmes et al., 2015; Lamarque et al., 2012) with the component set "FSDCHM" at a horizontal resolution of $1.9 \times 2.5^{\circ}$, with 56 vertical levels. This component set includes the tropospheric chemistry version of CAM4-chem forced with specified dynamics from year 2010 of the MERRA reanalysis (Rienecker et al., 2011). $\mathrm{NO}_{x}, \mathrm{O}_{3}, \mathrm{HNO}_{3}, \mathrm{~N}_{2} \mathrm{O}_{5}, \mathrm{~N}_{2} \mathrm{O}, \mathrm{CO}$, and $\mathrm{CH}_{4}$ are relaxed towards climatological values in the stratosphere. For this study, we replace the default chemical mechanism with the base mechanism from Emmons et al. (2012), modified as described in Sect. 3. Emissions of anthropogenic species are taken from the HTAP_v2.2 emission inventory (JanssensMaenhout et al., 2015). Biomass burning emissions are from GFEDv3 (van der Werf et al., 2010). Emissions of $\mathrm{NO}_{x}$ from lightning are calculated online within the model according to Price et al. (1997). Biogenic emissions of $\mathrm{NO}_{x}$ (from soils) and VOC (from vegetation) are prescribed as in Tilmes et al. (2015). Mixing ratios of $\mathrm{CH}_{4}$ and $\mathrm{N}_{2} \mathrm{O}$ are fixed at the surface as in Tilmes et al. (2015).

Model runs are carried out using both $\mathrm{NO}_{x}$ and VOC tagging, with the base chemical mechanism and model source code modified in each case as described in Sect. 3. We specify separate tag identities for emissions from anthropogenic (ANT), biogenic (BIO), biomass burning (BMB), and aircraft (AIR) sources. For $\mathrm{NO}_{x}$-tagging runs we specify an additional tag for $\mathrm{NO}_{x}$ from lightning (LGT), and for VOCtagging runs we specify an additional tag for methane (CH4). Furthermore, in our VOC-tagging run, we tag $\mathrm{CO}$ emissions from ANT, BIO, and BMB sources separately from the nonmethane VOC (NMVOC) emissions. In both cases $\left(\mathrm{NO}_{x}\right.$ and VOC tagging) we include tags representing chemical production in the stratosphere (STR), extra chemical production (XTR, as described in Sect. 3), and a special tag representing the initial conditions (INI), allowing us to monitor the progress of the model spin-up. This choice of tag identities allows us to compare our source attribution with that of Emmons et al. (2012), who used a similar set of tag identities, on which our new tagging scheme is based.

Initial conditions for $\mathrm{O}_{x}$ species were tagged with STR in the stratosphere and INI in the troposphere. Following Emmons et al. (2012), we used a chemical tropopause definition of $150 \mathrm{ppb}$ of ozone. Initial methane in the VOC-tagging run was tagged with $\mathrm{CH} 4$. The concentration of INI-tagged and STR-tagged species was set equal to the mixing ratio of the corresponding species in the initial conditions, and all other tagged tracers were set to zero at the beginning of the model run. The model was run with annually repeating meteorology from 2010 until the maximum contribution of surface ozone attributable to the initial conditions was less than $1 \%$ of the total surface ozone, and the maximum difference between the stratospheric contribution to surface ozone in December and the stratospheric contribution to surface ozone in the previous December was also less than $1 \%$. For VOC tagging we
Table 1. Contribution to annual average tropospheric ozone burden from tagged $\mathrm{NO}_{x}$ sources and transport from the stratosphere.

\begin{tabular}{lrr}
\hline $\begin{array}{l}\text { Source tag } \\
\left(\mathrm{NO}_{x} \text { tagging) }\right.\end{array}$ & $\begin{array}{r}\text { Contribution to } \\
\text { tropospheric } \\
\text { ozone burden (Tg) }\end{array}$ & $\begin{array}{r}\text { Percent } \\
\text { contribution }\end{array}$ \\
\hline Stratosphere & 75.7 & 23.7 \\
Anthropogenic & 111 & 34.9 \\
Lightning & 81.2 & 25.4 \\
Biogenic & 26.1 & 8.17 \\
Aircraft & 12.3 & 3.84 \\
Biomass burning & 11.5 & 3.59 \\
Other & 1.47 & 0.46 \\
\hline
\end{tabular}

imposed the additional constraint that the difference between the contribution of methane to surface ozone in December and the contribution in the previous December was less than $1 \%$. This was achieved after 2 years of simulation for $\mathrm{NO}_{x^{-}}$ tagged runs and 3 years of simulation for VOC-tagged runs. For the final year of simulation in each case (the second year for a $\mathrm{NO}_{x}$-tagged run and the third year for a VOC-tagged run), we verified that the method was working as expected by comparing the sum of the tagged ozone tracers with the actual ozone simulated by the model. At the lowest model level, the maximum monthly average difference was of the order of $1 \times 10^{-5} \mathrm{ppb}$, while in the free troposphere the maximum monthly average difference was of the order of $1 \mathrm{ppb}$. The actual ozone simulated when using a model modified for tagging is identical to the actual ozone simulated using an unmodified version of the model. The final year of simulation for both $\mathrm{NO}_{x}$ - and VOC-tagged runs is presented and discussed in Sect. 5.

\section{Results}

The contribution of each tagged source of $\mathrm{NO}_{x}$ and VOCs to the annual average global tropospheric burden of ozone is presented in Table 1 (for $\mathrm{NO}_{x}$ tagging) and Table 2 (for VOC tagging). Following Emmons et al. (2012) and Young et al. (2013), we define the troposphere as all model grid cells with an ozone mixing ratio lower than $150 \mathrm{ppb}$. Our simulation for the year 2010 produces a total tropospheric ozone burden of $320 \mathrm{Tg}\left(\mathrm{O}_{3}\right)$. This ozone burden is within 1 standard deviation of the multi-model mean reported by Young et al. (2013) for the year $2000\left(337 \pm 23 \mathrm{Tg}\left(\mathrm{O}_{3}\right)\right)$.

Our source attribution is consistent with previous results noting the strong sensitivity of tropospheric ozone to anthropogenic $\mathrm{NO}_{x}$ and biogenic VOC emissions (e.g. Young et al., 2013; Stevenson et al., 2013). A strong sensitivity of modelled tropospheric ozone to the mixing ratio of methane has also been noted in previous work (e.g. Fiore et al., 2008; Young et al., 2013). Direct comparison of our results with previous tagging studies is difficult due to the methodologi- 
Table 2. Contribution to annual average tropospheric ozone burden from tagged sources of VOC and CO, and transport from the stratosphere. Sources of NMVOC and CO were further tagged as being of either anthropogenic, biogenic, or biomass burning origin. The contribution of these different individual source categories to the tropospheric ozone burden are also shown here in addition to the total contributions of each of these chemical species.

\begin{tabular}{lrrrrr}
\hline & \multicolumn{3}{c}{ Contribution to tropospheric ozone burden (Tg) } & \\
\cline { 2 - 5 } $\begin{array}{l}\text { Source tag } \\
\text { (VOC tagging) }\end{array}$ & Anthropogenic & Biogenic & $\begin{array}{r}\text { Biomass } \\
\text { burning }\end{array}$ & Total & $\begin{array}{r}\text { Percent } \\
\text { contribution }\end{array}$ \\
\hline Stratosphere & - & - & - & 66.9 & 20.9 \\
Methane & - & - & - & 113 & 35.4 \\
NMVOC & 26.4 & 73.1 & 4.25 & 104 & 32.5 \\
CO & 18.6 & 3.24 & 9.43 & 31.3 & 9.78 \\
Other & - & - & - & 4.65 & 1.45 \\
\hline
\end{tabular}

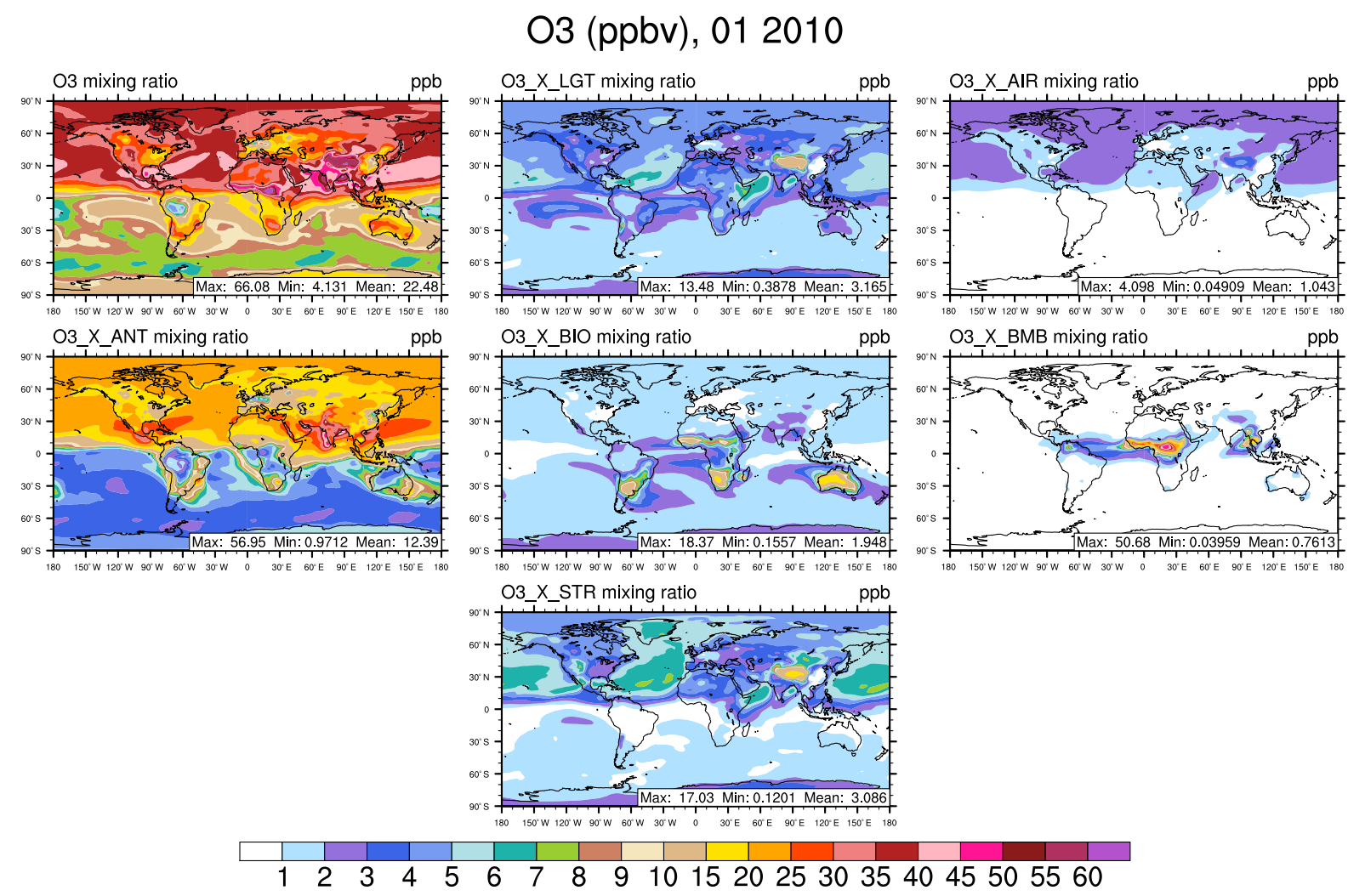

Figure 1. Surface ozone in January from the $\mathrm{NO}_{x}$-tagging run. Total surface ozone is shown in the top left panel. Other panels show the contribution to surface ozone due to $\mathrm{NO}_{x}$ precursors emitted by lightning (LGT), aircraft (AIR), anthropogenic sources (ANT), biogenic sources (BIO), biomass burning (BMB), and transport from the stratosphere (STR).

cal differences noted in Sect. 2. Grewe et al. (2017) combine the effects of $\mathrm{NO}_{x}$ and VOC precursors, whereas our results report their influences on tropospheric ozone separately. Emmons et al. (2012) do not report the contributions of their tagged sources to the tropospheric ozone burden.

The stratospheric contribution to tropospheric ozone burden under $\mathrm{NO}_{x}$ tagging $\left(75.7 \mathrm{Tg}\left(\mathrm{O}_{3}\right)\right.$, Table 1$)$ is higher than the corresponding contribution under VOC tagging $\left(66.9 \mathrm{Tg}\left(\mathrm{O}_{3}\right)\right.$, Table 2). Since the direct production of stratosphere-tagged ozone is identical in both runs, this difference of $8.8 \mathrm{Tg}\left(\mathrm{O}_{3}\right)$ must be due to ozone production involving stratosphere-tagged $\mathrm{NO}$, produced from the reaction of $\mathrm{N}_{2} \mathrm{O}$ with excited oxygen as described in Sect. 3.1.2. Grewe et al. (2017) previously noted a contribution of approximately $15 \mathrm{Tg}\left(\mathrm{O}_{3}\right)$ of this source to the tropospheric ozone burden (their Fig. 5e). We are not aware of any other previous work quantifying the contribution of $\mathrm{N}_{2} \mathrm{O}$ to the photochemical production of ozone in the troposphere. We 


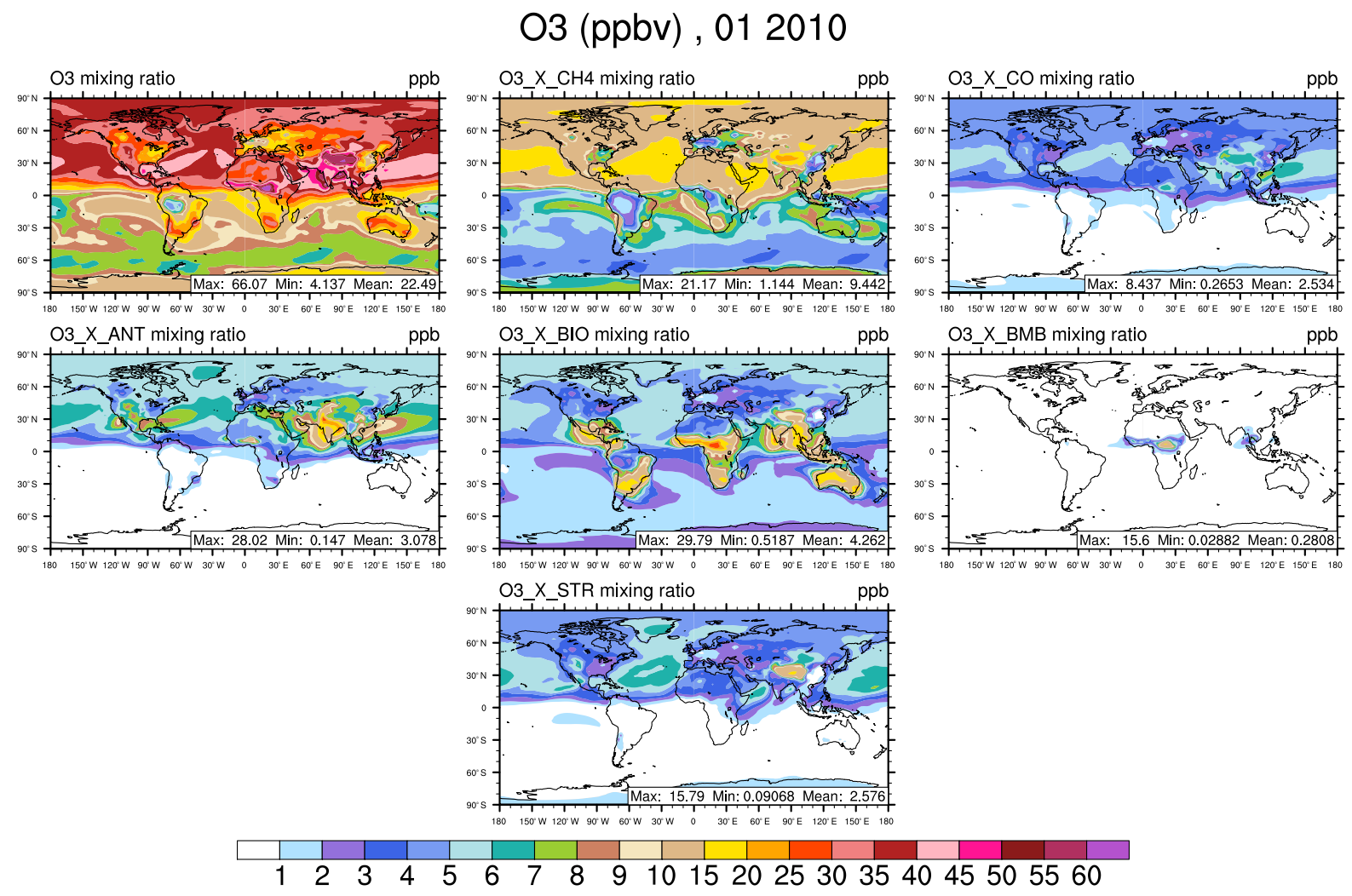

Figure 2. Surface ozone in January from the VOC-tagging run. Total surface ozone is shown in the top left panel. Other panels show the contribution to surface ozone due to methane (CH4), all CO emissions (CO), anthropogenic NMVOC sources (ANT), biogenic NMVOC sources (BIO), biomass burning NMVOC sources (BMB), and transport from the stratosphere (STR).

note that our model does not include a comprehensive treatment of stratospheric chemistry and associated stratospheretroposphere exchange. While our model does explicitly represent the photochemistry of $\mathrm{O}_{2}$ and $\mathrm{N}_{2} \mathrm{O}$ in the stratosphere, the mixing ratios of $\mathrm{O}_{x}$ and $\mathrm{NO}_{y}$ species are also relaxed towards climatological values in the stratosphere. Future work examining the contribution of stratospheric $\mathrm{NO}_{x}$ to tropospheric ozone production should implement our tagging methodology in a fully coupled stratosphere-troposphere model.

The rest of this section focuses on the contribution of tagged sources to the mixing ratio of ozone at the surface. The January average surface ozone mixing ratio along with the mixing ratios of major contributing sources are shown from the $\mathrm{NO}_{x}$-tagging run in Fig. 1 and from the VOCtagging run in Fig. 2. Similarly, the July average surface ozone mixing ratio is shown for the $\mathrm{NO}_{x}$-tagged and VOCtagged runs in Figs. 3 and 4. A complete set of figures showing the contribution of each tagged source to the monthly average mixing ratio of ozone at the surface, for each month of our simulation, for both $\mathrm{NO}_{x}$ and VOC tagging, can be found in Sect. 2 of the Supplement. January-December from the $\mathrm{NO}_{x}$-tagging run are shown in Figs. S1-S12 in the Sup- plement, and January-December from the VOC-tagging run are shown in Figs. S13-S24.

Over the Northern Hemisphere mid-latitude continental regions, modelled surface ozone has its maximum in summer and its minimum in winter. Over the remote Northern Hemisphere ocean regions, the opposite is the case; modelled surface ozone concentrations are higher in winter than they are in summer. These changes are strong enough in our model that in the northern mid-latitudes the land-sea gradient of modelled total surface ozone reverses sign between January and July. Low modelled surface ozone mixing ratios over the northern mid-latitudes in winter are consistent with high local emissions of $\mathrm{NO}_{x}$, and ozone removal by Reaction (R8). Examination of the tagged ozone tracers from both the $\mathrm{NO}_{x}$-tagged run and the VOC-tagged run shows that high modelled surface ozone mixing ratios over the northern mid-latitudes in summer are primarily attributable to a combination of anthropogenic $\mathrm{NO}_{x}$ emissions and biogenic NMVOC emissions, which is consistent with previous work (e.g. Young et al., 2013; Stevenson et al., 2013). Anthropogenic NMVOCs contribute relatively little to modelled high surface ozone mixing ratios in the boreal summer. This difference is consistent with the relatively high reactivity of biogenic NMVOC, especially isoprene, as well as the 
O3 (ppbv), 072010

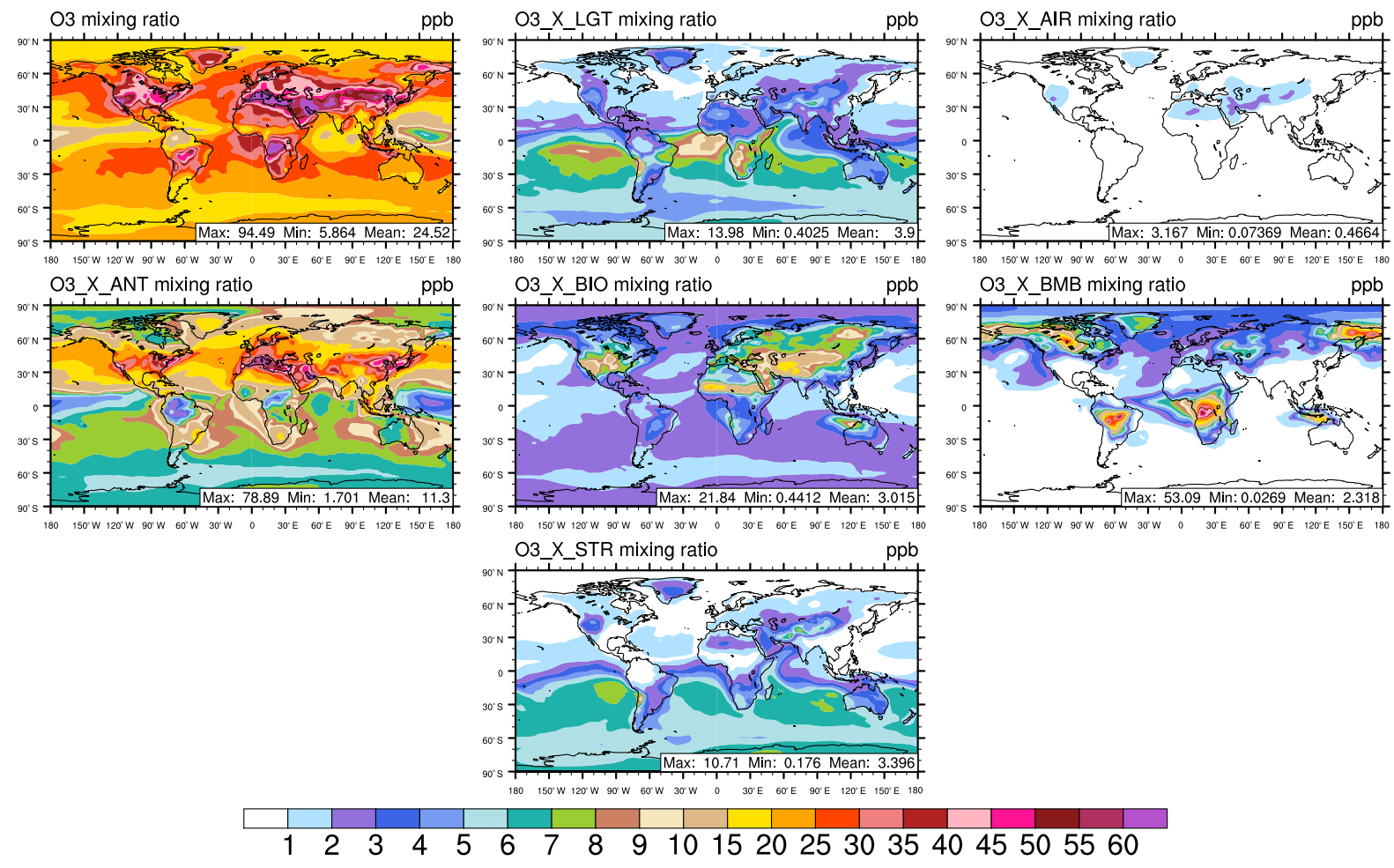

Figure 3. Surface ozone in July from the $\mathrm{NO}_{x}$-tagging run. Total surface ozone is shown in the top left panel. Other panels show the contribution to surface ozone due to $\mathrm{NO}_{x}$ precursors emitted by lightning (LGT), aircraft (AIR), anthropogenic sources (ANT), biogenic sources (BIO), biomass burning (BMB), and transport from the stratosphere (STR).

strong seasonal cycle in biogenic NMVOC emissions in midlatitude regions, being emitted almost exclusively during the growing season.

Low modelled surface ozone mixing ratios over the remote northern hemispheric ocean regions in summer are consistent with a stronger chemical sink due to photolysis of ozone with subsequent production of $\mathrm{OH}$ radicals from water vapour (Johnson et al., 1999). The strength of this sink decreases during the boreal winter, allowing modelled ozone to build up over large regions of the remote Northern Hemisphere. This northern hemispheric background ozone reaches a maximum in March-April (please refer to the Supplement) before the chemical sink increases again. Examination of the tagged ozone tracers from both the $\mathrm{NO}_{x}$-tagged run and the VOC-tagged run shows that this boreal winter-spring remote maritime build-up of ozone is primarily attributable to both anthropogenic $\mathrm{NO}_{x}$ and NMVOC emissions. This is in contrast to the summer maximum in surface ozone modelled over continental regions, for which the primary responsible NMVOC precursor is of biogenic origin (in both hemispheres). We are not aware of any previous work in the peerreviewed literature showing that anthropogenic NMVOCs contribute disproportionately to springtime ozone over remote regions of the Northern Hemisphere.
Another noteworthy feature of Figs. 2 and 4 is the strong contribution of methane to the modelled mixing ratio of ozone at the surface, in both January and July in both hemispheres, consistent with its high contribution to the total tropospheric ozone burden (Table 2). Here, we show that the contribution of surface ozone attributable to methane as an organic precursor remains remarkably constant at about $15 \mathrm{ppb}$ over large regions of the Northern Hemisphere yearround (at least in our model).

The influence of the stratosphere on the modelled ozone mixing ratio at the surface is stronger in winter than in summer in both hemispheres. The stratospheric influence on Northern Hemisphere surface ozone is smallest in July and August and reaches a maximum in March (please refer to the Supplement), when the contributions from the stratosphere and the organic precursors methane and anthropogenic VOCs to the northern hemispheric background ozone are approximately equal. The late-winter, early-spring maximum in the stratospheric contribution to surface ozone in the Northern Hemisphere is consistent with both an increased lifetime of tropospheric ozone during this period and the increasing flux of ozone from the stratosphere, which is consistent with the earlier work of Roelofs and Lelieveld (1997), who also used 


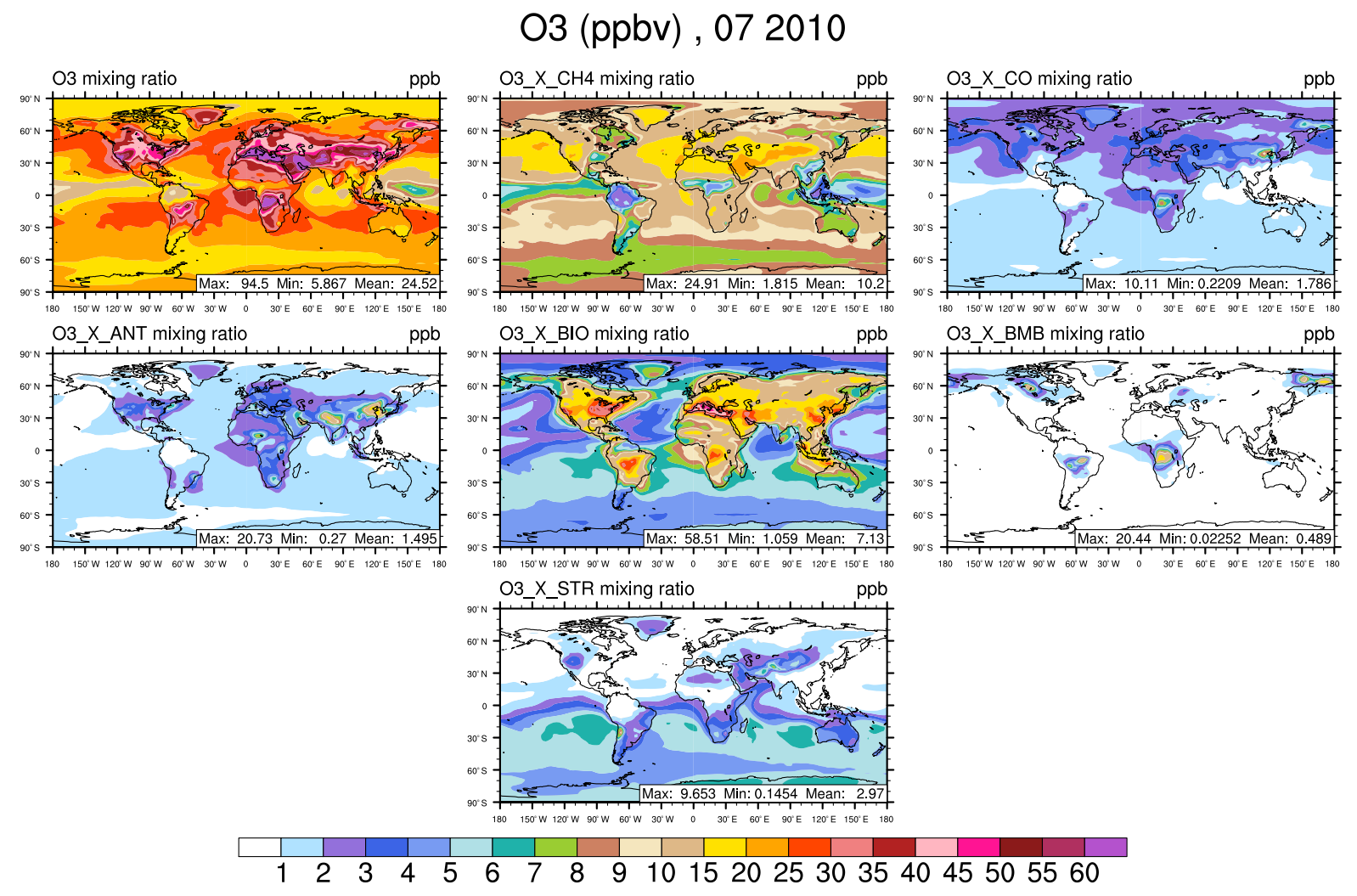

Figure 4. Surface ozone in July from the VOC-tagging run. Total surface ozone is shown in the top left panel. Other panels show the contribution to surface ozone due to methane (CH4), all CO emissions (CO), anthropogenic NMVOC sources (ANT), biogenic NMVOC sources (BIO), biomass burning NMVOC sources (BMB), and transport from the stratosphere (STR).

a stratospheric ozone tracer to determine the contribution of the stratosphere to surface ozone.

Emmons et al. (2012) determined the contribution of stratospheric ozone to the modelled mixing ratio of ozone at the surface using their tagging approach. Since they did not explicitly tag the ozone originating in the stratosphere, they calculated the stratospheric contribution to tropospheric ozone as the residual after subtracting all of the ozone which had been produced from tagged tropospheric sources. They found that their residual stratospheric contribution to surface ozone was less than half of the contribution determined using a stratospheric tracer such as that used by Roelofs and Lelieveld (1997), which is set equal to the ozone mixing ratio in the stratosphere and removed from the troposphere at the same rate as ozone itself. Emmons et al. (2012) pointed out that such a stratospheric ozone tracer is likely to give an upper bound on the stratospheric contribution to surface ozone due to the fact that the tagged stratospheric ozone is set equal to the total ozone mixing ratio in the stratosphere, which effectively overwrites any tropospheric ozone which may have been imported into the stratosphere. In contrast to the use of a stratospheric tracer, we regard the residual estimate of Emmons et al. (2012) as a lower bound on the contribution of stratospheric ozone to surface ozone, due to the overwriting problem mentioned above, in which their ozone tag identities are overwritten with the identity of nearby sources.

Figure 5 shows the contribution of each of our tag identities to the zonally averaged ozone at the surface and at $400 \mathrm{hPa}$ from our $\mathrm{NO}_{x}$-tagging run. This figure is designed to be directly comparable with Fig. 6 of Emmons et al. (2012). Our simulated zonal average total ozone mixing ratio is broadly similar with that of Emmons et al. (2012) in both January and July, but there are some noteworthy differences in contributions of the tagged tracers; the stratospheric contribution to surface ozone shows particularly large differences. We model a zonally averaged stratospheric contribution to surface ozone of approximately $8 \mathrm{ppb}$ in each winter hemisphere (Northern Hemisphere in January and Southern Hemisphere in July). These results are similar to those of Emmons et al. (2012) in the Southern Hemisphere, but approximately double those in the Northern Hemisphere winter, for which Emmons et al. (2012) attribute only about $4 \mathrm{ppb}$ of surface ozone to stratospheric origin. The lower stratospheric contribution to Northern Hemisphere surface ozone from Emmons et al. (2012) is consistent with their bias towards nearby sources due to the tag overwriting problem, as noted above. Similarly, Emmons et al. (2012) estimate a higher (by approximately $5 \mathrm{ppb}$ ) contribution of anthro- 


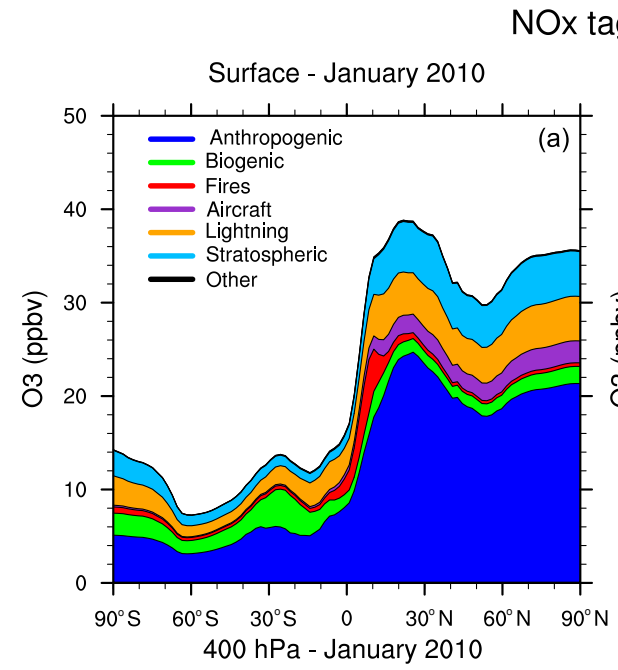

tagging
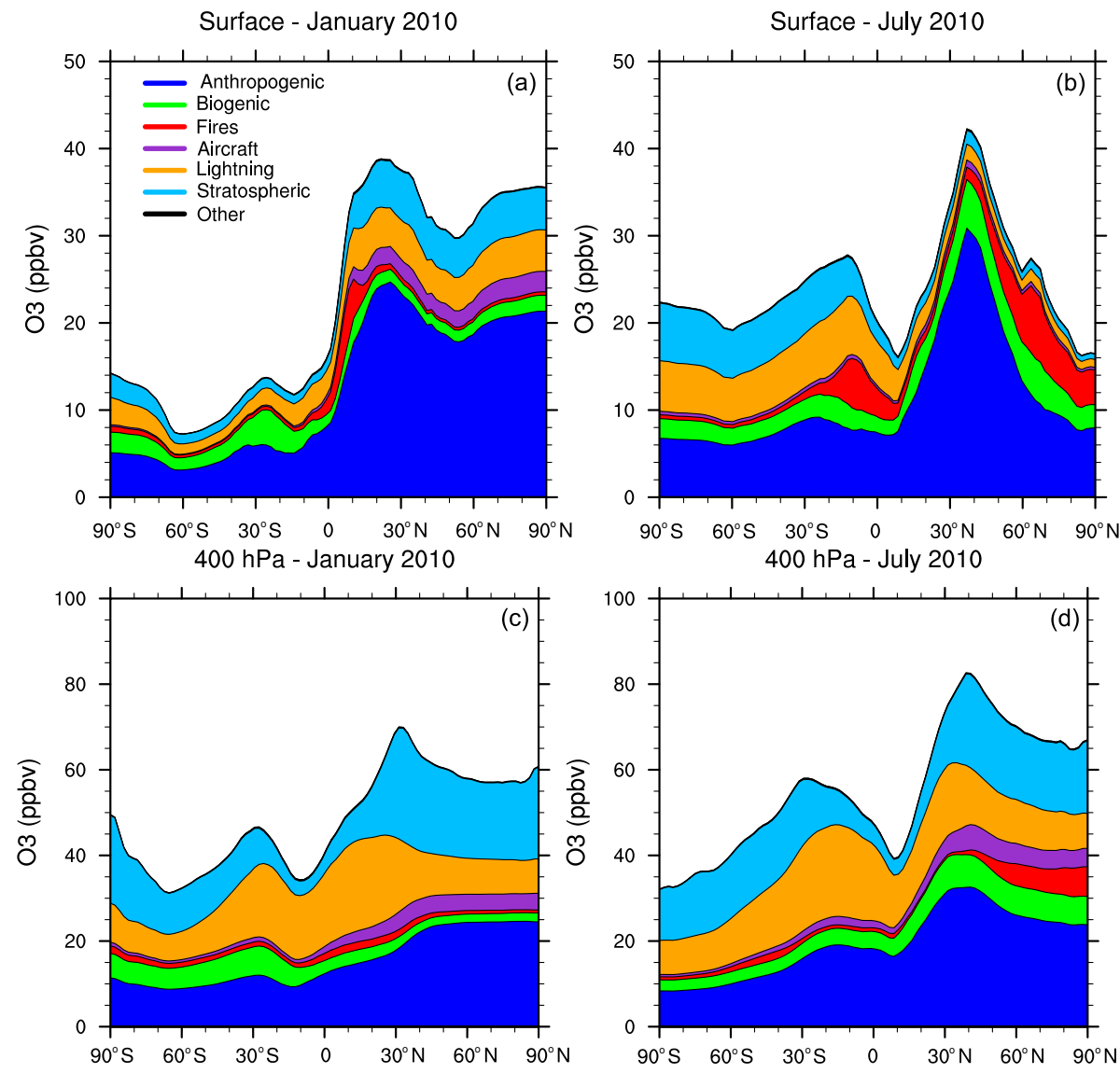

Figure 5. Zonal average of tagged ozone source contributions at the surface (a, b) and at $400 \mathrm{hPa}(\mathbf{c}, \mathbf{d})$ for January (a, c) and July (b, d) from the $\mathrm{NO}_{x}$-tagging run.

pogenic emissions to zonal average surface ozone than we see in our Fig. 5 and show effectively no stratospheric contribution in July, while our run shows a small contribution of about $3 \mathrm{ppb}$ of stratospheric ozone to northern hemispheric surface ozone in July. These results illustrate the importance of explicitly separating tagged species which are members of both the $\mathrm{NO}_{y}$ and $\mathrm{O}_{x}$ families to preserve the tagged identities of ozone transported over long distances. The contribution of the tagged VOC precursors to zonal average surface ozone is shown in Fig. 6. The widespread, year-round contribution of methane to ozone production is clearly visible, as is the increased importance of anthropogenic NMVOCs as an ozone precursor during the boreal winter, noted earlier.

\section{Conclusions}

We have introduced and described a technique for attribution of tropospheric ozone to emitted precursors of both $\mathrm{NO}_{x}$ and VOC, as well as transport from the stratosphere. The results obtained using this technique are consistent with understand- ing of tropospheric ozone chemistry based on previous work. Our work shares features with many earlier methodologies for attribution of tropospheric ozone, but combines these features in unique ways which allow a unique and deeper understanding of the processes influencing tropospheric ozone in our model and avoid many of the problems associated with previous work such as over-attribution of ozone to locally emitted precursors and the unphysical transfer of tag identities between $\mathrm{NO}_{x}$ and VOC species.

By performing simultaneous but separate attribution of ozone to both its $\mathrm{NO}_{x}$ and VOC precursors, we have quantified, for example, the changing contributions of anthropogenic and biogenic sources to modelled seasonal cycles of surface ozone over the populated and remote regions of the Northern Hemisphere. In particular, we have identified the combination of anthropogenic $\mathrm{NO}_{x}$ and anthropogenic VOC as a significant contributor to the widespread buildup of ozone over the Northern Hemisphere during winterspring in our model, in contrast with a relatively insignificant role for anthropogenic VOC in summer ozone production, for which biogenic VOCs play a more important role. Fur- 

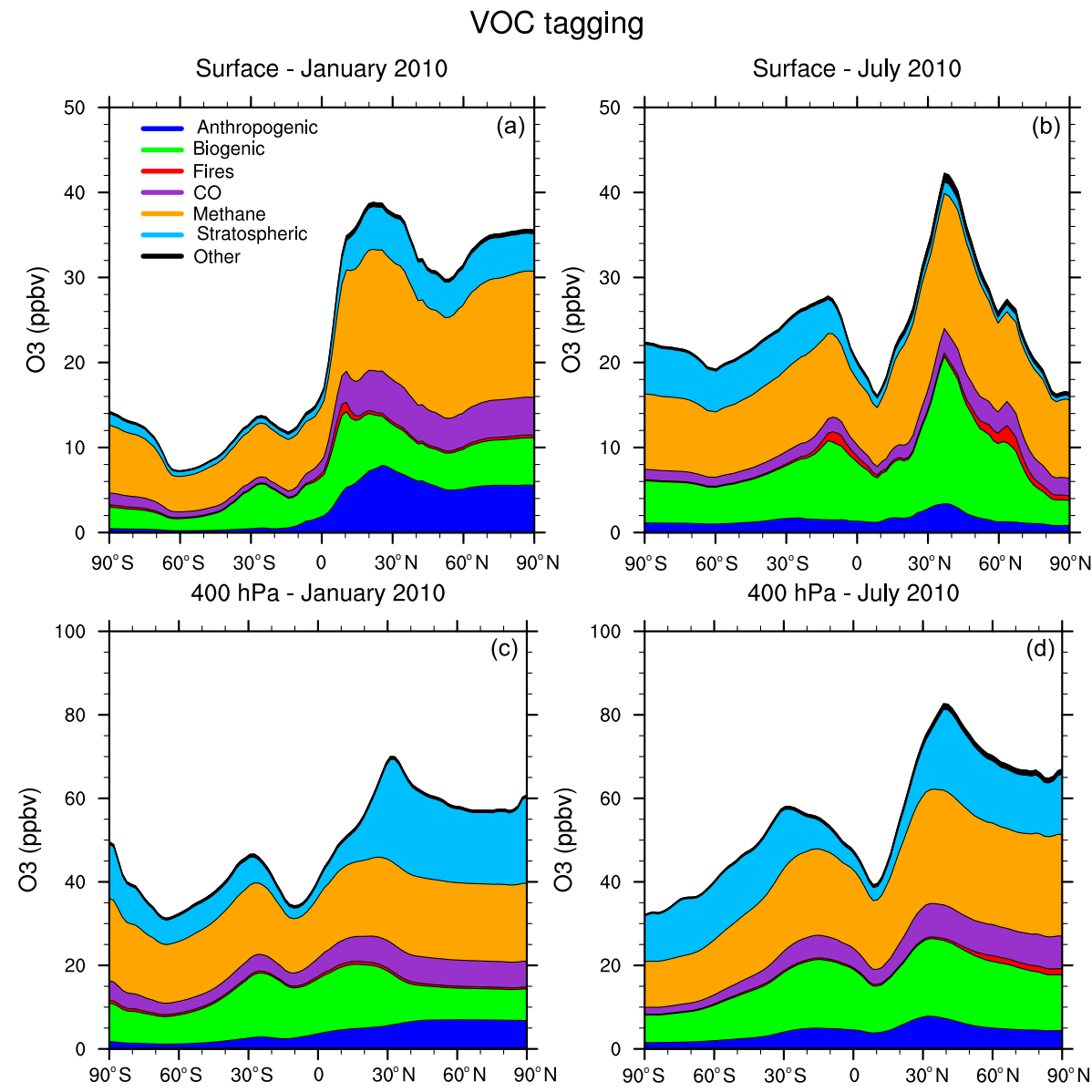

Figure 6. Zonal average of tagged ozone source contributions at the surface (a, b) and at $400 \mathrm{hPa}$ (c, d) for January (a, c) and July (b, d) from the VOC-tagging run.

ther experiments using this tagging technique should examine the winter-spring contribution of anthropogenic VOCs in more detail. Such experiments could instead tag anthropogenic VOC emissions according to their source sector, geographical region, time of emission, or even according to the particular kinds of VOC molecules emitted, in order to understand more about the ultimate sources of this springtime ozone in different receptor regions. Future work using this tagging technique could also examine the change in the contribution of all ozone precursors to tropospheric ozone when individual sources are perturbed. For example, it would be possible to quantify the change in the contribution of methane oxidation to modelled tropospheric ozone when anthropogenic $\mathrm{NO}_{x}$ emissions are reduced by some amount.

Given the problems of the current generation of global chemistry-climate models in simulating amounts, trends, and seasonal cycles of tropospheric ozone, the deeper understanding provided by our tagging methodology may yield information about deficiencies in these models and point the way towards improvements. If implemented in additional chemistry-climate models, our methodology could be a use- ful tool in understanding the differing responses of different models to changes in precursor emissions. Given the large number of alternative methodologies for attribution of tropospheric ozone, including the several different ways of implementing tagging which have been reviewed here, we also believe that the community would benefit from a systematic intercomparison of the different techniques for constructing source-receptor relationships of tropospheric ozone.

Code availability. The full suite of tagging tools, input files, and machine-readable tagged mechanism files are included in the Supplement.

Supplement. The supplement related to this article is available online at: https://doi.org/10.5194/gmd-11-2825-2018-supplement. 
Author contributions. TB conceived and designed the study. TB implemented the automatic mechanism-rewriting and codegeneration tools. ZS and AL adapted the CESM source code. AL performed the model runs and subsequent analysis. AL and JC both contributed tools for analysing the model runs. TB wrote the paper.

Competing interests. The authors declare that they have no conflict of interest.

Acknowledgements. This work was hosted by IASS Potsdam, with financial support provided by the Federal Ministry of Education and Research of Germany (BMBF) and the Ministry for Science, Research and Culture of the State of Brandenburg (MWFK).

Edited by: Gerd A. Folberth

Reviewed by: two anonymous referees

\section{References}

Atkinson, R.: Atmospheric chemistry of VOCs and $\mathrm{NO}_{x}$, Atmos. Environ., 34, 2063-2101, 2000.

Butler, T., Lawrence, M., Taraborrelli, D., and Lelieveld, J.: Multiday ozone production potential of volatile organic compounds calculated with a tagging approach, Atmos. Environ., 45, 40824090, https://doi.org/10.1016/j.atmosenv.2011.03.040, 2011.

Clappier, A., Belis, C. A., Pernigotti, D., and Thunis, P.: Source apportionment and sensitivity analysis: two methodologies with two different purposes, Geosci. Model Dev., 10, 4245-4256, https://doi.org/10.5194/gmd-10-4245-2017, 2017.

Coates, J. and Butler, T. M.: A comparison of chemical mechanisms using tagged ozone production potential (TOPP) analysis, Atmos. Chem. Phys., 15, 8795-8808, https://doi.org/10.5194/acp15-8795-2015, 2015.

Derwent, R. G., Utembe, S. R., Jenkin, M. E., and Shallcross, D. E.: Tropospheric ozone production regions and the intercontinental origins of surface ozone over Europe, Atmos. Environ., 112, 216-224, https://doi.org/10.1016/j.atmosenv.2015.04.049, 2015.

Dunker, A., Yarwood, G., Ortmann, J., and Wilson, G.: Comparison of source apportionment and source sensitivity of ozone in a three-dimensional air quality model, Environ. Sci. Technol., 36, 2953-2964, https://doi.org/10.1021/es011418f, 2002.

Emmons, L. K., Hess, P. G., Lamarque, J.-F., and Pfister, G. G.: Tagged ozone mechanism for MOZART-4, CAM-chem and other chemical transport models, Geosci. Model Dev., 5, 15311542, https://doi.org/10.5194/gmd-5-1531-2012, 2012.

Fiore, A. M., West, J. J., Horowitz, L. W., Naik, V., and Schwarzkopf, M. D.: Characterizing the tropospheric ozone response to methane emission controls and the benefits to climate and air quality, J. Geophys. Res., 113, D08307, https://doi.org/10.1029/2007JD009162, 2008.

Fiore, A. M., Dentener, F. J., Wild, O., Cuvelier, C., Schultz, M. G., Hess, P., Textor, C., Schulz, M., Doherty, R. M., Horowitz, L. W., MacKenzie, I. A., Sanderson, M. G., Shindell, D. T., Stevenson, D. S., Szopa, S., Van Dingenen, R., Zeng, G., Atherton, C., Bergmann, D., Bey, I., Carmichael, G., Collins, W. J., Duncan, B. N., Faluvegi, G., Folberth, G., Gauss, M., Gong, S., Hauglus- taine, D., Holloway, T., Isaksen, I. S. A., Jacob, D. J., Jonson, J. E., Kaminski, J. W., Keating, T. J., Lupu, A., Marmer, E., Montanaro, V., Park, R. J., Pitari, G., Pringle, K. J., Pyle, J. A., Schroeder, S., Vivanco, M. G., Wind, P., Wojcik, G., Wu, S., and Zuber, A.: Multimodel estimates of intercontinental sourcereceptor relationships for ozone pollution, J. Geophys. Res., 114, D04301, https://doi.org/10.1029/2008JD010816, 2009.

Grewe, V., Tsati, E., and Hoor, P.: On the attribution of contributions of atmospheric trace gases to emissions in atmospheric model applications, Geosci. Model Dev., 3, 487-499, https://doi.org/10.5194/gmd-3-487-2010, 2010.

Grewe, V., Tsati, E., Mertens, M., Frömming, C., and Jöckel, P.: Contribution of emissions to concentrations: the TAGGING 1.0 submodel based on the Modular Earth Submodel System (MESSy 2.52), Geosci. Model Dev., 10, 2615-2633, https://doi.org/10.5194/gmd-10-2615-2017, 2017.

Guo, Y., Liu, J., Mauzerall, D. L., Li, X., Horowitz, L. W., Tao, W., and Tao, S.: Long-Lived Species Enhance Summertime Attribution of North American Ozone to Upwind Sources, Environ. Sci. Technol., 51, 5017-5025, https://doi.org/10.1021/acs.est.6b05664, 2017.

Janssens-Maenhout, G., Crippa, M., Guizzardi, D., Dentener, F., Muntean, M., Pouliot, G., Keating, T., Zhang, Q., Kurokawa, J., Wankmüller, R., Denier van der Gon, H., Kuenen, J. J. P., Klimont, Z., Frost, G., Darras, S., Koffi, B., and Li, M.: HTAP_v2.2: a mosaic of regional and global emission grid maps for 2008 and 2010 to study hemispheric transport of air pollution, Atmos. Chem. Phys., 15, 11411-11432, https://doi.org/10.5194/acp-15-11411-2015, 2015.

Johnson, C., Collins, W., Stevenson, D., and Derwent, R.: Relative roles of climate and emissions changes on future tropospheric oxidant concentrations, J. Geophys. Res.-Atmos., 104, 1863118645, 1999.

Kwok, R. H. F., Baker, K. R., Napelenok, S. L., and Tonnesen, G. S.: Photochemical grid model implementation and application of VOC, $\mathrm{NO}_{x}$, and $\mathrm{O}_{3}$ source apportionment, Geosci. Model Dev., 8, 99-114, https://doi.org/10.5194/gmd-8-99-2015, 2015.

Lamarque, J.-F., Emmons, L. K., Hess, P. G., Kinnison, D. E., Tilmes, S., Vitt, F., Heald, C. L., Holland, E. A., Lauritzen, P. H., Neu, J., Orlando, J. J., Rasch, P. J., and Tyndall, G. K.: CAM-chem: description and evaluation of interactive atmospheric chemistry in the Community Earth System Model, Geosci. Model Dev., 5, 369-411, https://doi.org/10.5194/gmd-5369-2012, 2012.

Lamarque, J.-F., Shindell, D. T., Josse, B., Young, P. J., Cionni, I., Eyring, V., Bergmann, D., Cameron-Smith, P., Collins, W. J., Doherty, R., Dalsoren, S., Faluvegi, G., Folberth, G., Ghan, S. J., Horowitz, L. W., Lee, Y. H., MacKenzie, I. A., Nagashima, T., Naik, V., Plummer, D., Righi, M., Rumbold, S. T., Schulz, M., Skeie, R. B., Stevenson, D. S., Strode, S., Sudo, K., Szopa, S., Voulgarakis, A., and Zeng, G.: The Atmospheric Chemistry and Climate Model Intercomparison Project (ACCMIP): overview and description of models, simulations and climate diagnostics, Geosci. Model Dev., 6, 179-206, https://doi.org/10.5194/gmd-6179-2013, 2013.

Monks, P. S., Archibald, A. T., Colette, A., Cooper, O., Coyle, M., Derwent, R., Fowler, D., Granier, C., Law, K. S., Mills, G. E., Stevenson, D. S., Tarasova, O., Thouret, V., von Schneidemesser, E., Sommariva, R., Wild, O., and Williams, M. L.: Tropospheric 
ozone and its precursors from the urban to the global scale from air quality to short-lived climate forcer, Atmos. Chem. Phys., 15, 8889-8973, https://doi.org/10.5194/acp-15-8889-2015, 2015.

Parrish, D., Lamarque, J.-F., Naik, V., Horowitz, L., Shindell, D., Staehelin, J., Derwent, R., Cooper, O., Tanimoto, H., VolzThomas, A., Gilge, S., Scheel, H.-E., Steinbacher, M., and Fröhlich, M.: Long-term changes in lower tropospheric baseline ozone concentrations: Comparing chemistry-climate models and observations at northern midlatitudes, J. Geophys. Res., 119, 5719-5736, https://doi.org/10.1002/2013JD021435, 2014.

Price, C., Penner, J., and Prather, M.: $\mathrm{NO}_{\mathrm{x}}$ from lightning 1. Global distribution based on lightning physics, J. Geophys. Res.-Atmos., 102, 5929-5941, 1997.

Rienecker, M. M., Suarez, M. J., Gelaro, R., Todling, R., Bacmeister, J., Liu, E., Bosilovich, M. G., Schubert, S. D., Takacs, L., Kim, G.-K., Bloom, S., Chen, J., Collins, D., Conaty, A., da Silva, A., Gu, W., Joiner, J., Koster, R. D., Lucchesi, R., Molod, A., Owens, T., Pawson, S., Pegion, P., Redder, C. R., Reichle, R., Robertson, F. R., Ruddick, A. G., Sienkiewicz, M., and Woollen, J.: MERRA: NASA's Modern-Era Retrospective Analysis for Research and Applications, J. Climate, 24, 3624-3648, https://doi.org/10.1175/jcli-d-11-00015.1, 2011.

Roelofs, G.-J. and Lelieveld, J.: Model study of the influence of cross-tropopause $\mathrm{O}_{3}$ transports on tropospheric $\mathrm{O}_{3}$ levels, Tellus B, 49, 38-55, 1997.

Saunders, S. M., Jenkin, M. E., Derwent, R. G., and Pilling, M. J.: Protocol for the development of the Master Chemical Mechanism, MCM v3 (Part A): tropospheric degradation of nonaromatic volatile organic compounds, Atmos. Chem. Phys., 3, 161-180, https://doi.org/10.5194/acp-3-161-2003, 2003.

Sillman, S.: The use of $\mathrm{NO}_{y}, \mathrm{H}_{2} \mathrm{O}_{2}$, and $\mathrm{HNO}_{3}$ as indicators for ozone- $\mathrm{NO}_{x}$-hydrocarbon sensitivity in urban locations, J. Geophys. Res., 100, 14175-14188, 1995.

Stevenson, D. S., Young, P. J., Naik, V., Lamarque, J.-F., Shindell, D. T., Voulgarakis, A., Skeie, R. B., Dalsoren, S. B., Myhre, G., Berntsen, T. K., Folberth, G. A., Rumbold, S. T., Collins, W. J., MacKenzie, I. A., Doherty, R. M., Zeng, G., van Noije, T. P. C., Strunk, A., Bergmann, D., Cameron-Smith, P., Plummer, D. A., Strode, S. A., Horowitz, L., Lee, Y. H., Szopa, S., Sudo, K., Nagashima, T., Josse, B., Cionni, I., Righi, M., Eyring, V., Conley, A., Bowman, K. W., Wild, O., and Archibald, A.: Tropospheric ozone changes, radiative forcing and attribution to emissions in the Atmospheric Chemistry and Climate Model Intercomparison Project (ACCMIP), Atmos. Chem. Phys., 13, 3063-3085, https://doi.org/10.5194/acp-13-3063-2013, 2013.
Sudo, K. and Akimoto, H.: Global source attribution of tropospheric ozone: Long-range transport from various source regions, J. Geophys. Res., 112, D12302, https://doi.org/10.1029/2006jd007992, 2007.

Tilmes, S., Lamarque, J.-F., Emmons, L. K., Kinnison, D. E., Ma, P.-L., Liu, X., Ghan, S., Bardeen, C., Arnold, S., Deeter, M., Vitt, F., Ryerson, T., Elkins, J. W., Moore, F., Spackman, J. R., and Val Martin, M.: Description and evaluation of tropospheric chemistry and aerosols in the Community Earth System Model (CESM1.2), Geosci. Model Dev., 8, 1395-1426, https://doi.org/10.5194/gmd8-1395-2015, 2015.

van der Werf, G. R., Randerson, J. T., Giglio, L., Collatz, G. J., Mu, M., Kasibhatla, P. S., Morton, D. C., DeFries, R. S., Jin, Y., and van Leeuwen, T. T.: Global fire emissions and the contribution of deforestation, savanna, forest, agricultural, and peat fires (1997-2009), Atmos. Chem. Phys., 10, 11707-11735, https://doi.org/10.5194/acp-10-11707-2010, 2010.

Wang, Y., Jacob, D. J., and Logan, J. A.: Global simulation of tropospheric $\mathrm{O}_{3}-\mathrm{NO}_{x}$-hydrocarbon chemistry: 3. Origin of tropospheric ozone and effects of nonmethane hydrocarbons, J. Geophys. Res.-Atmos., 103, 10757-10767, https://doi.org/10.1029/98jd00156, 1998.

Ying, Q. and Krishnan, A.: Source contributions of volatile organic compounds to ozone formation in southeast Texas, J. Geophys. Res.-Atmos., 115, D17306, https://doi.org/10.1029/2010JD013931, 2010.

Young, P. J., Archibald, A. T., Bowman, K. W., Lamarque, J.-F., Naik, V., Stevenson, D. S., Tilmes, S., Voulgarakis, A., Wild, O., Bergmann, D., Cameron-Smith, P., Cionni, I., Collins, W. J., Dalsøren, S. B., Doherty, R. M., Eyring, V., Faluvegi, G., Horowitz, L. W., Josse, B., Lee, Y. H., MacKenzie, I. A., Nagashima, T., Plummer, D. A., Righi, M., Rumbold, S. T., Skeie, R. B., Shindell, D. T., Strode, S. A., Sudo, K., Szopa, S., and Zeng, G.: Preindustrial to end 21 st century projections of tropospheric ozone from the Atmospheric Chemistry and Climate Model Intercomparison Project (ACCMIP), Atmos. Chem. Phys., 13, 2063 2090, https://doi.org/10.5194/acp-13-2063-2013, 2013. 